\title{
The Correlation Between Asthma Severity and Neutrophil to Lymphocyte Ratio
}

\author{
Meena Abdul-Sattar Darwesh, Ibtihal Shukri Abd Alhaleem, and Mohammed Waheeb Al-Obaidy
}

\begin{abstract}
-
Background-The prognosis is essential in management and follows up of asthmatic patients. Neutrophil to lymphocyte ratio is considered as the common prognostic marker for many diseases especially the asthma.

Aim of study-To assess the relationship between asthma severity and neutrophil to lymphocyte ratio in comparison to healthy controls.

Patients and methods-This study is a cross sectional study conducted in Respiratory Consultancy Clinic in Baghdad Teaching Hospital in Medical City during the period from 1st of October, 2018 to 31st of March, 2019 on sample of 50 asthmatic patients and 50 healthy controls. The diagnosis of asthma was confirmed by the supervisor through clinical symptoms, signs, spirometery with reversibility test (according to GINA guideline.).

Results-A highly significant difference was observed between asthmatic cases and controls regarding age $(p<0.001)$. A significant association was observed between obesity and asthmatic cases $(p=0.001)$. There was a highly significant association between high neutrophil/lymphocyte ratio and asthmatic cases $(p<0.001)$. The neutrophil/lymphocyte ratio was significantly increased with advanced age, females, severe and uncontrolled asthma.
\end{abstract}

Conclusions - The neutrophil to lymphocyte ratio is useful biomarker in assessment of asthma severity.

\section{Index Terms-Asthma, Neutrophil to Lymphocyte Ratio.}

\section{INTRODUCTION}

Asthma is the most common chronic inflammatory disease of the airways in the population. Chronic inflammation caused by mediators released from mast cells, eosinophils, neutrophils, macrophages, lymphocytes, and some other cells has been detected in the airways of asthmatic patients [1].

Recent studies have demonstrated that neutrophilic inflammation is related to an increase in the severity of the disease [2]. In addition, the existence of eosinophilic inflammation in asthma has been shown to be related to atopy and symptoms of persistent asthma [3].

A definition of the similar biological indicators that play a role in inflammation in asthma is important since this will open the gate for further developments in diagnosis and treatment. During childhood asthma, in particular, special

Published on March 26, 2020

M. A. Darwesh, Iraqi Ministry of Health, Medical City Complex, Baghdad Teaching Hospital, Iraq.

I. S. A. Alhaleem, Iraqi Ministry of Health, Health Al-Karkh Directorate, Iraq.

M. W. Al-Obaidy, Iraqi Ministry of Higher Education and Scientific Research, Medical Department at College of Medicine- University of Baghdad, Iraq.

(e-mail:dmwalobaidi@comed.eubaghdad.edu.iq,mwalobaidy@gmail.com) non-invasive asthma indicators for monitoring and followup are of great importance because existing diagnostic techniques cannot be used properly due to their invasiveness or the need for cooperation. Commonly used Spiro metric measurements require effective cooperation, whereas bronchoalveolar lavage (BAL) is invasive [4]. Therefore, there is a need for non-invasive methods that can be used to monitor asthma. Chronic inflammation is also present in asthma.

Cytokines in the pathogenesis of asthma cause an increase in neutrophils, as noted above [1], [2]. Based on this information, we consider that the NLR is increased in asthmatics. However, our knowledge regarding NLR in Asthmatic patients is incomplete [5], [6]. Although a previous study in adults revealed no relationship between asthma and NLR, [5] NLR was found to be associated with neutrophilic asthma in the second study [6]. Neutrophil tolymphocyte ratio (NLR) has been studied in medical and surgical populations.

It is a prognostic marker of morbidity and mortality for numerous conditions, including cardiovascular disease [7], oncology [8], critical care medicine [9], liver disease [10], general surgery, and vascular surgery [11]. It was recently associated with all-cause mortality in hemodialysis (HD) patients [12].

\section{A. Neutrophils and respiratory diseases}

With the changing of global environment, especially the increased air Pollution worldwide, respiratory diseases are becoming a main killer to Human health. According to recent researches, asthma is ranked as the 14th most important chronic disease, affecting 334 million individuals of all ages worldwide [13]. Lung is the leading cancer site in males, comprising $17 \%$ of the total new cancer cases and $23 \%$ of the total cancer deaths [14].

As for COPD, affecting 64 million people all over the world, it would be the third most common cause of death by 2030. Community acquired pneumonia is a common cause of sepsis, leading to 10 million deaths annually [15]. While epidemiology data of idiopathic pulmonary fibrosis (IPF) worldwide cannot be obtained, IPF incidence is still increasing and carries a high risk of respiratory failure and death [16].

Respiratory diseases not only increase the economic burden of global health care but also cause a terrible effect on the quality of daily life.

Although the precise treatment of respiratory diseases has made a great progress, the pathogenesis of them still needs further elucidation [17].

Innate together with adaptive immunity, as natural systematic defensive barrier, is composed of immune organs, cells, and cytokines [18]. The innate immunity is a 
natural defense that shapes in the process of long-time biological evolution. As the first barrier to defend infection, innate immunity participates in the resistance to pathogenic invasion and the clearance of aging, injured and even mutant cells nonspecifically. Innate immunity was firstly reported in the development of immunology and was becoming the focus of immunological research in recent twenty years, especially after the discovery of various kinds of pattern recognition receptors (PRRs) and innate lymphoid cells (ILCs) [19]. When the exogenous threats cannot be removed by innate immunity successfully, adaptive immunity will take part in the important defensive battle. Adaptive immunity system including humoral and cellular immunity often plays a leading role in the final clearance of invasive pathogens. The executors are $\mathrm{T}$ lymphoid cells and $\mathrm{B}$ lymphoid cells, who can both recognize antigens specifically. Different immune cells can exert protective and defensive effect synergistically with the help of multiple cytokines and protein molecules. The mechanism of adaptive immunity has been being gradually clarified since the birth of immunology. Various monoclonal antibody medicines related with adaptive immunity such as rituximab and infliximab have brought a wonderful curative effect in many refractory diseases including respiratory diseases [20].

Traditionally, neutrophils, originating in bone marrow stem cells, had only been considered as a kind of innate immune cell [21]. As an essential component of innate immunity, neutrophils play an important role in killing pathogens and removing cellular debris [22]. The migration and activation of neutrophils could cause inflammation and sensitization directly or indirectly. Inflammation caused by self-immune system is really important for the solution of infection and clearance of pathogens. But the persistent inflammation in respiratory system frequently leads to some adverse diseases such as asthma, COPD, and pulmonary fibrosis. In addition, neutrophils can synergize with lymphocytes and other granulocytes, such as Th2/Th17 and eosinophils, to participate in not only innate but also adaptive immune process and promote airway inflammation [23]. The interaction between neutrophils and other immune cells, endogenous composition, and foreign matter is very complex andbeing clarified thoroughly [22].

There have been more and more studies on the role of neutrophils in respiratory diseases. Recently, exosomes, neutrophil extracellular traps (NETs), deriving from neutrophil and the higher autophagy of neutrophils have been reported in multiple respiratory diseases [24]. Despite that the pathogeneses of respiratory diseases are being studied extensively, there is still a long way to go to clarify the complexity and heterogeneity, especially the participation of various immune components in the development of respiratory diseases [20].

\section{B. Asthmatic neutrophils}

As Global Initial for Asthma (GINA, updated in 2017) elucidated [25], asthma is a heterogeneous disease, always characterized by expiratory airflow limitation and chronic inflammation. Asthma is usually categorized as different phenotypes and endotypes according to its different clinical characteristics and distinct pathological mechanism.

Traditionally, asthma was classified as four different phenotypes [26], eosinophilic, neutrophilic, mixed granulocytic asthma, and paucicellular asthma according to the cellular counts of sputum, bronchoalveolar lavage fluid (BALF), or peripheral blood [27]. For example, Jodie et al. distinguished asthmatics with neutrophil proportion in sputum over $61 \%$ as neutrophilic asthma [28]. However, more and more researches have demonstrated the instability of asthma phenotypes [29]. Neutrophil as an essential granulocyte has been reported by many investigators to play a critical role in many immunity-associated diseases including asthma, especially steroid-refractory severe asthma [30]. High blood neutrophils counts are associated with an increased risk of moderate, but not severe asthma exacerbation. At the same time, the neutrophil-predominant asthmatics also tend to show a lower bronchial liability [31].

\section{Neutrophils participation in asthma}

Lower respiratory tracts used to be considered as sterile. But more and more evidence had already showed us the conflicted results. Moraxella catarrhalis or a member of the Haemophilus or Streptococcus genera was discovered colonizing in the lower airways of asthmatics [32]. These species' colonization was associated with more differential sputum neutrophil counts and worse clinical disease status. The altered colonization would participate in the development of asthma phenotype. Infection of H. influenza could synergize with allergic airway diseases to induce Th17 immune responses that drive the development of neutrophilic asthma. The process above is mediated by IL17 responses.

In addition, subclinical infection likely contributes to neutrophilic inflammation in airways [33].

Microbial components, which contain LPS and $\beta$-glucan, could synergistically cause neutrophilic asthma mediated by TLR-4 and dectin-1, whose deficiency could significantly attenuate the recruitment of neutrophils induced by house dust mite (HDM) into airways [34]. Blood neutrophils from allergic asthma also show the chemotactic and phagocytic activities towards LPS and asthmatic serum [35].

Asthmatics challenged with inhaled Dermatophagoides pteronyssinus (DP) would promote the production of neutrophil chemotaxis. Siew et al. demonstrated that neutrophil chemotaxis induced by smoke and other environmental stimulations could also be helpful for developing inflammation in airways [36].

As described above, smoking and other infectious factors can cause the accumulation of neutrophils in BALF. This is associated with the activation of phosphatidylinositol 3kinase (PI3K) signal. Phosphatidylinositol 3-kinases (PI3Ks), as the key elements in the signaling cascades, play an important role in the chemotaxis of neutrophils. In particular, $\mathrm{PI} 3 \mathrm{~K} \delta$ and $\mathrm{PI} 3 \mathrm{~K} \gamma$ isoforms contribute to inflammatory cell recruitment and subsequent activation [37].

The traditional role of different PI3K isoforms in the chemotaxis of neutrophils had already been reviewed previously [38]. PI3K $\gamma$ deficiency could significantly reduce the influx of neutrophils into BALF.

PI3K $\delta$ inhibition may also prevent recruitment of neutrophils. The PI3Krelated inflammation and steroid insensitivity should partly be attributed to microRNA- 
21/PI3K/histone deacetylase 2 (HDAC2) axis as Kim et al. reported. In addition, the activation of PI3K is accompanied with the release of all kinds of chemokines and cytokines, such as IL-6 and IL-8, which are related with the increased chemotactic activity of neutrophils towards the inflamed sites. Not only the chemotactic activity of neutrophils but also the concrete details of neutrophil activation mechanism have been making progress in recent years [39].

\section{Potential Targeted Therapy}

It is believed that the failure of targeting neutrophils could be attributed to an incomplete understanding of underlying mechanism of neutrophilic asthma. New insights into emerging neutrophil biology and underlying mechanisms of neutrophil phenotype might come to be the evidences of precision-based medicine. ICS is still the firstline medicine for ameliorating syndromes. Coinhalation of roflumilast and fluticasone, which reduces the counts of both neutrophils and eosinophils in BALF, could significantly improve the inflammatory condition in OVAinduced mice compared with the combination of formoterol and fluticasone [52].

Manually synthetic chemical drugs have an important curative effect on various diseases all along. Simvastatin, as an effective serum cholesterollowering agent could reduce the percentage of neutrophil in BALF and improve airway inflammation and remodeling in obese asthma mice. Tamoxifen had a direct action on equine peripheral blood neutrophils and dampened the respiratory burst production. Rosiglitazone (RSG), a peroxisome proliferator-activated receptor- $\gamma$ agonist, has been reported to attenuate airway inflammation by inhibiting the proliferation of effector $\mathrm{T}$ cells in a murine model of neutrophilic asthma in vivo. It can also downregulate the ratio of Treg and Th17 cells, inhibit the secretion of Th2 cytokines, and further inhibit the airway inflammatory response in asthma mice effectively [53]. AZD5069 as an antagonist of CXCR2, a receptor promoting neutrophils back to the inflamed airways, could reversibly reduce circulating neutrophils' count. SCH527132, a selective CXCR2 receptor antagonist, can reduce sputum neutrophils and tend to improve the Asthma Control Questionaire scores of asthma [52].

Medicine from various plants has composed a large part in health care filed. Ligustrazine, water extract of Helminthostachys zeylanica (L.) Hook, astragalin as an antiinflammatory flavonoid present in persimmon leaves and green tea seeds, hydroethanolic extract (70\%) of M.longiflora (HEMI), bufalin and cordycepin could target to the neutrophils, intervene the different inflammatory signaling pathways, and improve the prognosis of asthma. Biopharmaceutical has become a new treatment for asthma in recent years. Recombinant human activated protein $\mathrm{C}$ (rhAPC)could attenuate HDM + LPS-induced neutrophil migration in allergic asthma. Another recombination protein, recombinant human IL-4, could inhibit airway inflammation in bronchial asthma by reducing the cytokines and inflammatory cells including neutrophils. Medicine from plants and targeted biopharmaceuticals has a huge potential to play amajor role in future medical field [54].

\section{E. Aim of study}

To assess the relationship between asthma severity and neutrophil to Lymphocyte ratio in comparison to healthy controls.

\section{PATIENTS AND Method}

\section{A. Study design and settings}

This study is a cross sectional study conducted in Respiratory Consultancy Clinic in Baghdad Teaching Hospital in Medical City during the period from 1st of October, 2018 to 31st of March, 2019.

\section{B. Study population}

All asthmatic patients presented to Respiratory Consultancy Clinic in Baghdad Teaching Hospital was the study population.

\section{Inclusion criteria}

1. Adults (age $\geq 20$ years).

2. Confirmed diagnosis of asthma. (According to GINA guideline.)

\section{Exclusion criteria}

1. Children and adolescents.

2. Smokers.

3. Signs of infection like fever, cough and sputum.

4. Renal diseases.

5. Liver diseases.

6. Cardiovascular diseases.

7. Other chronic diseases.

\section{E. Sampling}

A sample of 50 asthmatic patients presented to Respiratory Consultancy Clinic in Baghdad Teaching Hospital was selected after eligibility to Inclusion and exclusion criteria. A convenient sample of 50 healthy controls was selected from relatives accompanying patients in the Clinic.

\section{F. Data Collection}

The data was collected by researcher from study participants directly and filled in a prepared questionnaire. The questionnaire was designed by the supervisor and researcher. The questionnaire included the followings.

1. Demographic characteristics of study participants: Age and gender.

2. Educational level of study participants.

3. Body mass index of study participants.

4. Blood film of study participants: WBC, $\mathrm{Hb}$, neutrophils and lymphocyte.

5. Spirometry findings of study participants: FVC, FVC\%, FEV1, FEV1\%, FEV/FVC.

6. Neutrophil to lymphocyte ratio (NLR).

\section{G. Assessment of study participants}

The diagnosis of asthma was confirmed by the supervisor through clinical symptoms, signs, spirometry with reversibility test which were done in Respiratory Clinic of Baghdad Teaching Hospital. After taking full history and examination of study participants, a sample of $5 \mathrm{ml}$ venous blood was drawn from patients and sent for Laboratory of Baghdad Teaching Hospital to acquire the blood film and specifically NLR of all study participants. The normal limit 
values of NLR were: 0.78-3.53 [55].

\section{H. Ethical considerations}

1. The ethical approval was taken from hospital authorities.

2. The researcher helped in diagnosis and management of asthma.

3. An oral informed consent was taken from all study participants.

\section{Statistical analysis}

All study participants' data entered using computerized statistical software; Statistical Package for Social Sciences (SPSS) version 20 was used. Descriptive statistics presented as (mean \pm standard deviation) and frequencies as percentages. Multiple contingency tables conducted and appropriate statistical tests performed, Chi square test was used for categorical variables (Fishers exact test was used when expected variable was less than $20 \%$ of total variable). Independent sample t-test was used to compare between two means and one-way ANOVA analysis was used to compare between more than two means. In all statistical analysis, level of significance ( $p$ value) set at $\leq 0.05$ and the result presented as tables and/or graphs. Statistical analysis of the study was done by Specialist in Community Medicine.

\section{RESULTS}

In present study 100 study participants were included; 50 asthmatic cases and 50 healthy controls. A highly significant difference was observed between asthmatic cases and controls regarding age $(\mathrm{p}<0.001) ; 16 \%$ of asthmatic cases were 50 years age and more. No significant differences were observed between asthmatic cases and controls regarding gender $(p=0.6)$ and educational level $(p=0.2)$. A significant association was observed between obesity and asthmatic cases $(p=0.001) ; 42 \%$ of asthmatic cases were obese. All these findings were shown in Table I and Fig. 1.

TABLE I: DISTRIBUTION OF GENERAL CHARACTERISTICS ACCORDING TO ASTHMATIC CASES AND CONTROLS

\begin{tabular}{|c|c|c|c|c|c|}
\hline \multirow{2}{*}{ Variable } & \multicolumn{2}{|c|}{ Asthmatic } & \multicolumn{2}{|c|}{ Control } & \multirow{2}{*}{$\mathbf{P}$} \\
\hline & No. & $\%$ & No. & $\%$ & \\
\hline \multicolumn{6}{|l|}{ Age } \\
\hline$<30$ years & 14 & 28.0 & 18 & 36.0 & \multirow{4}{*}{$<0.001 * \mathrm{~s}$} \\
\hline $30-39$ years & 12 & 24.0 & 28 & 56.0 & \\
\hline $40-49$ years & 16 & 32.0 & 4 & 8.0 & \\
\hline$\geq 50$ years & 8 & 16.0 & 0 & - & \\
\hline \multicolumn{6}{|l|}{ Gender } \\
\hline Male & 24 & 48.0 & 26 & 52.0 & \multirow[t]{2}{*}{$0.6 * * \mathrm{NS}$} \\
\hline Female & 26 & 52.0 & 24 & 48.0 & \\
\hline \multicolumn{6}{|l|}{ BMI } \\
\hline Normal & 17 & 34.0 & 20 & 40.0 & \multirow{3}{*}{$0.001 * * \mathrm{~S}$} \\
\hline Overweight & 12 & 24.0 & 25 & 50.0 & \\
\hline Obese & 21 & 42.0 & 5 & 10.0 & \\
\hline \multicolumn{6}{|c|}{ Educational level } \\
\hline Illiterate & 7 & 14.0 & 7 & 14.0 & \multirow{4}{*}{$0.2 * * \mathrm{NS}$} \\
\hline Primary & 20 & 40.0 & 12 & 24.0 & \\
\hline Secondary & 13 & 26.0 & 14 & 28.0 & \\
\hline College & 10 & 20.0 & 17 & 34.0 & \\
\hline
\end{tabular}

*Fishers exact test, ${ }^{* *}$ Chi-square test, NS=Not significant, $\mathrm{S}=$ Significant.

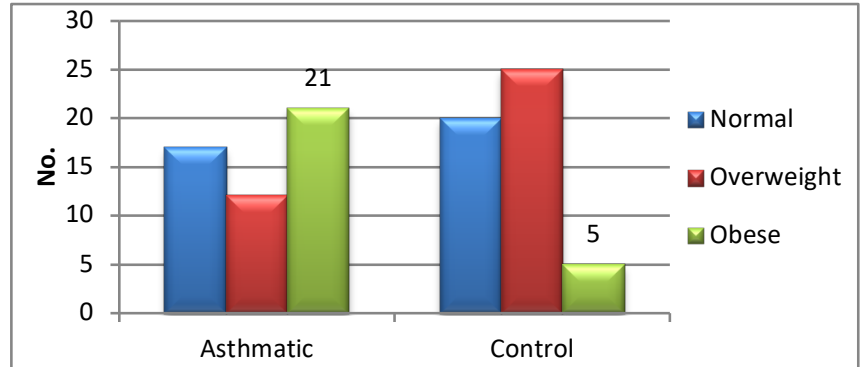

Fig. 1. Distribution of BMI according to asthmatic cases and controls

Mean WBC count of asthmatic patients was 8.3 which was significantly higher than 7.3 mean of WBC for controls $(\mathrm{p}=0.03)$. No significant differences were observed between asthmatic cases and controls regarding neutrophils mean $(\mathrm{p}=0.2)$, lymphocytes mean $(\mathrm{p}=0.2)$ and $\mathrm{Hb}$ mean $(\mathrm{p}=0.8)$. Mean FVC of asthmatic cases was 3.3 which was significantly lower than mean FVC of 3.7 for healthy controls $(p=0.04)$. Mean FVC\% of asthmatic cases was 67.8 that was significantly lower than $\mathrm{FVC} \%$ for controls $(p<0.001)$. The FEV1 mean of asthmatic cases (2.2) was significantly lower than FEV1 of (3) for controls $(p<0.001)$. Mean FEV1\% for asthmatic cases was $62.7 \%$ that was significantly lower $85.6 \%$ for controls $(p<0.001)$. Mean FEV1/FVC for asthmatic cases was $66.5 \%$ that was significantly lower than FEV1/FVC of $81.4 \%$ for controls $(\mathrm{p}<0.001)$. All these findings were shown in Table II and Fig. 2.

TABLE II: DISTRIBUTION OF INVESTIGATIONS MEASURES ACCORDING TO ASTHMATIC CASES AND CONTROLS

\begin{tabular}{lccc}
\hline \hline Variable & $\begin{array}{c}\text { Asthmatic } \\
\text { Mean } \pm \text { SD }\end{array}$ & $\begin{array}{c}\text { Control } \\
\text { Mean } \pm \text { SD }\end{array}$ & P \\
\hline WBC $\left(\times 10^{3}\right)$ & $8.3 \pm 3$ & $7.3 \pm 1.3$ & $0.03 * \mathrm{~S}$ \\
Neutrophil & $62.7 \pm 19.3$ & $66.5 \pm 9.5$ & $0.2 * \mathrm{NS}$ \\
FVC & $3.3 \pm 0.9$ & $3.7 \pm 1.1$ & $0.04 * \mathrm{~S}$ \\
FVC\% & $67.8 \pm 14.3$ & $\mathbf{8 4 . 3} \pm 5.5$ & $<0.001 * \mathrm{~S}$ \\
Lymphocyte & $30.4 \pm 16.9$ & $\mathbf{2 7 . 5} \pm 4.1$ & $0.2 * \mathrm{NS}$ \\
FEV1 & $2.2 \pm 0.9$ & $3 \pm 0.9$ & $<0.001 * \mathrm{~S}$ \\
FEV1\% & $62.7 \pm 18.1$ & $\mathbf{8 5 . 6} \pm 6.5$ & $<0.001 * \mathrm{~S}$ \\
Hb & $13.9 \pm 2.7$ & $13.9 \pm 1.1$ & $0.8 * \mathrm{NS}$ \\
FEV1/FVC\% & $66.5 \pm 16.9$ & $\mathbf{8 1 . 4} \pm 6.9$ & $<0.001 * \mathrm{~S}$ \\
\hline \hline
\end{tabular}

* Independent sample t-test, $\mathrm{S}=$ Significant.

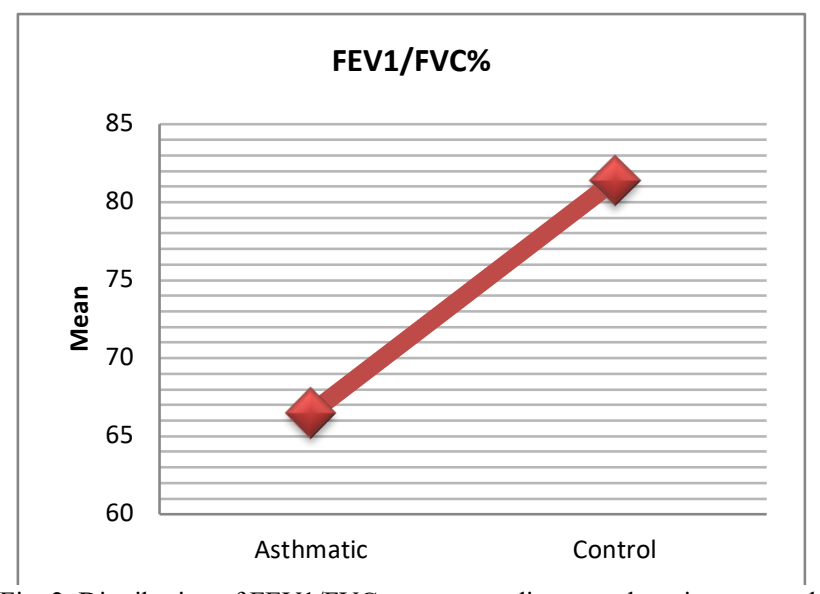

Fig. 2. Distribution of FEV1/FVC mean according to asthmatic cases and controls

There was a highly significant association between high neutrophil/lymphocyte ratio and asthmatic cases $(\mathrm{p}<0.001)$; $8 \%$ of asthmatic cases had low NLR while $24 \%$ of asthmatic cases had high NLR ratio in comparison to $2 \%$ of controls with high NLR. All these findings were shown in Table III 
and Fig. 3.

TABLE III: DISTRIBUTION OF NLR ACCORDING TO ASTHMATIC CASES AND CONTROLS

\begin{tabular}{lccccc}
\hline \hline \multirow{2}{*}{ Variable } & \multicolumn{2}{c}{ Asthmatic } & \multicolumn{2}{c}{ Control } & \multirow{2}{*}{ P } \\
& No. & $\%$ & No. & $\%$ & \\
\hline NLR & & & & & \\
Low & 4 & 8.0 & 0 & - & $<0.001 * \mathrm{~S}$ \\
Normal & 34 & $\mathbf{6 8 . 0}$ & 49 & 98.0 & \\
High & 12 & 24.0 & 1 & 2.0 & \\
\hline \hline
\end{tabular}

* Fishers exact test, $\mathrm{S}=$ Significant.

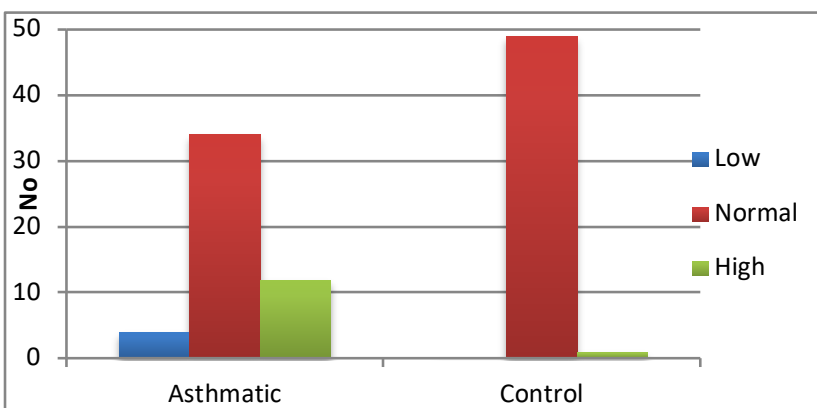

Fig. 3. Distribution of NLR according to asthmatic cases and controls

The mean NLR of asthmatic cases was significantly increased to 3.2 with increased age to 50 years and more $(\mathrm{p}=0.02)$. All these findings were shown in Table IV.

TABLE IV: DISTRIBUTION OF NLR OF ASTHMATIC CASES ACCORDING TO

\begin{tabular}{|c|c|c|c|c|c|}
\hline \multicolumn{6}{|c|}{ AGE GROUPS } \\
\hline Variable & $\begin{array}{l}<30 \text { years } \\
\text { Mean } \pm \text { SD }\end{array}$ & $\begin{array}{c}30-39 \\
\text { years } \\
\text { Mean } \pm \text { SD }\end{array}$ & $\begin{array}{c}40-49 \\
\text { years } \\
\text { Mean } \pm \text { SD }\end{array}$ & $\begin{array}{l}\geq 50 \text { years } \\
\text { Mean } \pm \text { SD }\end{array}$ & $\mathbf{P}$ \\
\hline NLR & $2.5 \pm 1.2$ & $2.3 \pm 0.7$ & $2.4 \pm 0.8$ & $3.2 \pm 1.6$ & $0.02 * \mathrm{~S}$ \\
\hline
\end{tabular}

* One way ANOVA analysis, $\mathrm{S}=$ Significant.

The mean NLR of asthmatic cases was significantly higher among females in comparison to males (2.8 vs. 2.3 ) $(p=0.04)$. All these findings were shown in Table V.

TABLE V: DISTRIBUTION OF NLR OF ASTHMATIC CASES ACCORDING TO GENDER

\begin{tabular}{lccc}
\hline \hline Variable & $\begin{array}{c}\text { Male } \\
\text { Mean } \pm \text { SD }\end{array}$ & $\begin{array}{c}\text { Female } \\
\text { Mean } \pm \text { SD }\end{array}$ & P \\
\hline NLR & $\mathbf{2 . 3} \pm \mathbf{1 . 1}$ & $\mathbf{2 . 8} \pm \mathbf{1 . 1}$ & $\mathbf{0 . 0 4}{ }^{* \mathrm{~S}}$ \\
\hline \hline
\end{tabular}

* Independent sample t-test, $\mathrm{S}=$ Significant.

No significant differences were observed in NLR between BMI categories of asthmatic cases $(p=0.3)$. All these findings were shown in Table VI.

TABLE VI: DISTRIBUTION OF NLR OF ASTHMATIC CASES ACCORDING TO BMI

\begin{tabular}{lcccc}
\hline \hline Variable & $\begin{array}{c}\text { Normal } \\
\text { Mean } \pm \text { SD }\end{array}$ & $\begin{array}{c}\text { Overweight } \\
\text { Mean } \pm \text { SD }\end{array}$ & $\begin{array}{c}\text { Obese } \\
\text { Mean } \pm \text { SD }\end{array}$ & P \\
\hline NLR & $\mathbf{2 . 7} \pm 1.4$ & $\mathbf{2 . 3} \pm \mathbf{0 . 6}$ & $\mathbf{3 . 6} \pm 1.3$ & $\mathbf{0 . 3}$ *NS $^{\mathrm{N}}$ \\
\hline \hline
\end{tabular}

* One way ANOVA analysis, NS=Not significant.

The mean NLR of asthmatic cases was significantly increased to 3.7 with increase of severity of asthma $(p<0.001)$. All these findings were shown in Table VII and Fig. 4.

TABLE VII: DISTRIBUTION OF NLR OF ASTHMATIC CASES ACCORDING TO SEVERITY

\begin{tabular}{lcccc}
\hline \hline Variable & $\begin{array}{c}\text { Mild } \\
\text { Mean } \pm \text { SD }\end{array}$ & $\begin{array}{c}\text { Moderate } \\
\text { Mean } \pm \text { SD }\end{array}$ & $\begin{array}{c}\text { Severe } \\
\text { Mean } \pm \text { SD }\end{array}$ & P \\
\hline NLR & $\mathbf{0 . 8} \pm \mathbf{0 . 7}$ & $\mathbf{2 . 2} \pm \mathbf{1 . 1}$ & $\mathbf{3 . 7} \pm \mathbf{1 . 4}$ & $<0.001{ }^{* \mathrm{~S}}$ \\
\hline \hline
\end{tabular}

* One way ANOVA analysis, $\mathrm{S}=$ Significant.

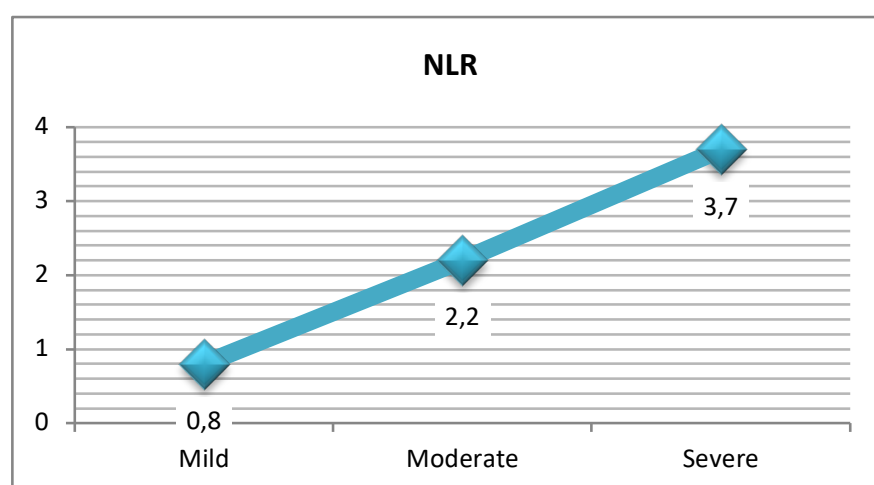

Fig. 4. Distribution of NLR according to severity of asthmatic cases

No significant differences were observed in NLR between duration groups of asthma for cases $(p=0.1)$. All these findings were shown in Table VIII.

TABLE VIII: DISTRIBUTION OF NLR OF ASTHMATIC CASES ACCORDING TO DURATION OF ASTHMA

\begin{tabular}{lccc}
\hline \hline Variable & $\begin{array}{l}<10 \text { years } \\
\text { Mean } \pm \text { SD }\end{array}$ & $\begin{array}{l}\geq 10 \text { years } \\
\text { Mean } \pm \text { SD }\end{array}$ & P \\
\hline NLR & $2.5 \pm 1.5$ & $3.2 \pm 1.5$ & $0.1^{* \text { NS }}$ \\
\hline \hline
\end{tabular}

* Independent sample t-test, NS=Not significant.

The mean NLR of asthmatic cases was significantly increased to 3.7 with no control of ACT categories of asthma $(\mathrm{p}<0.001)$. All these findings were shown in Table IX.

TABLE IX: DISTRIBUTION OF NLR OF ASTHMATIC CASES ACCORDING TO ACT CATEGORIES OF ASTHMA

\begin{tabular}{lcccc}
\hline \hline Variable & $\begin{array}{c}\text { Well controlled } \\
\text { Mean } \pm \text { SD }\end{array}$ & $\begin{array}{c}\text { On target } \\
\text { Mean } \pm \text { SD }\end{array}$ & $\begin{array}{c}\text { No control } \\
\text { Mean } \pm \text { SD }\end{array}$ & P \\
\hline NLR & $\mathbf{0 . 8} \pm 0.7$ & $2.2 \pm 1.1$ & $3.7 \pm 1.4$ & $<0.001 *$ S \\
\hline \hline
\end{tabular}

* One way ANOVA analysis, $\mathrm{S}=$ Significant.

\section{DISCUSSION}

Continuous monitoring of asthma management is the cornerstone in management. Assessment and follow up of management for asthmatic patients requires some methods like asthma control test (ACT) or assessing inflammation indicators like $\mathrm{C}$-reactive protein and neutrophil to lymphocyte ratio (NLR) [56].

Present study showed that high neutrophil/lymphocyte ratio was significantly associated with asthmatic patients in comparison to controls $(\mathrm{p}<0.001)$. This finding is consistent with results of Gungen and Aydemir study in Turkey [57] which found a significantly higher mean of NLR in asthmatic cases in comparison to controls. Many authors reported higher NLRs that commonly accompanied the inflammation, severity of disease, bad nutrition, long hospital stay duration, chronic diseases and high death rates related to these chronic diseases [58]-[60]. In other study, Nacaroglu et al [61] found that NLR is an effective predictor of acute asthmatic exacerbation in children. In China, Shi et al [62] study revealed that high NLR and platelets to lymphocyte ratio (PLR) are helpful in diagnosis and assessment of asthma. Elevated NLR is explained as the inflammatory markers are important in development of asthma specifically cytokines.

Increased levels of cytokines are associated with increased level of neutrophils [63]. These pro-inflammatory cytokines interleukin-6 and tumor necrosis factors are 
elevated in asthma which in turn increases immune cells like neutrophils and natural killer cells which also initiate the liver production of acute phase proteins like C-reactive protein in asthma [63], [64].

Current study showed that mean NLR of asthmatic cases was significantly increased among patients with severe asthma $(\mathrm{p}<0.001)$.

This finding coincides with results of Liu et al [54] study in China which stated that NLR level is obviously increased among patients with severe asthma. Recent Japanese study by Mochimaru et al [65] proved that NLR level is elevated among asthmatic adults with acute exacerbations.

Multiple studies detected the relationship between severe asthma and neutrophilic inflammation. The relationship between neutropils and severe asthma could be seen in eosinophilic and non-eosinophilic asthma66. The type 2 helper cells induced the neutrophilic inflammation [2].

In addition to asthma, higher levels of NLR is related to severity of many diseases like chronic obstructive pulmonary diseases, [64] inflammatory bowel diseases [67], liver diseases [68], renal diseases [69] and others.

Regarding ACT, our study showed that mean NLR of asthmatic cases was significantly increased with no control of ACT categories of asthma, while decreased with good control of asthma $(\mathrm{p}<0.001)$. This finding is similar to results of Hendy et al 70 study in Egypt which found that neutophil to lymphocyte ratio predicts accurately uncontrolled asthma according to ACT categories among patients with bronchial asthma. Bruijnzeel et al [71] study in Netherlands stated that neutrophils phenotypes are predictor of severity in severe neutropihlic asthma and NLR plays major role in prediction of asthma disease course and reflects the control of asthma with its positive direct relation to asthma control test (ACT).

In present study, there was a highly significant association between increased age and asthmatic patients $(\mathrm{p}<0.001)$. Similarly, Tarraf et al [72] documented that asthma in Middle East countries ranges from $4.4 \%$ to $6.7 \%$ prevalence and the demographic distribution revealed tendency toward be prevalent among adults and increased with increased of age.

Current Italian study reported that asthma in elderly population is difficult to diagnose and associated with many co-morbidities [73]. Our study showed that mean NLR of asthmatic cases was significantly increased with increased age to 50 years and more $(p=0.02)$. Consistently, Imtiaz et al [74] study in Pakistan reported that mean NLR of patients with chronic diseases was increased with increased age of patients. In USA, Zein et al [75] study revealed that older age patients had more severe asthma than younger age patients and this might be due to effect of age and duration of asthma. As a result, the NLR ratio was increased with severe asthma that is related to increased age [57]. Our study showed a significantly higher NLR among females in comparison to males $(p=0.04)$. This finding is in agreement with results of Lin et al [76] study in Netherlands which found that NLR and PLR are heritable and affected by age, gender and environmental factors. In this study, a significant association was observed between obesity and asthmatic cases $(p=0.001)$. This finding is consistent with results of Mohanan et al [77] study in USA which suggested more concentration on treatment of obesity during treatment of asthma due to strong relationship between them. Previous Iraqi study detected a significant correlation between obesity, age, gender and utilization of steroids with leptin level [78]. Our study showed higher white blood cells count for asthmatic patients in comparison to controls $(\mathrm{p}=0.03)$. Zhang et al [6] found that blood count parameters such as white blood cell count are useful in monitoring of uncontrolled asthma. Present study showed a significantly lower means of FVC and FVC1 of asthmatic patients in comparison to healthy controls. The FVC and FVC1 are spirometery parameters which are significantly reduced among asthmatic patients in comparison to healthy population and are regarded as diagnostic measures of asthma [79]. Similarly, our study showed a significantly lower means of FEV1, FEV1\% and FEV1/FVC\% among asthmatic patients in comparison to healthy controls. Many literatures proved the accuracy of sprometry measures of FEV1, FEV1\% and FEV1/FVC\% in diagnosis of asthma with lowe means of these measures in comparison to normal population [80], [81]. The main limitations in present study were single center study, selection bias and small sample size.

\section{CONCLUSiOnS}

1. The neutrophil to lymphocyte ratio is possibly important in severity assessment of asthma.

2. The neutrophil to lymphocyte ratio is possibly applicable in monitoring the management of asthma.

3. The neutrophil to lymphocyte ratio is dependable on age, gender, severity of asthma and asthma control test.

4. The asthma is more prevalent among older age and obesepopulation (in this group of study)

5. The blood count and spirometery parameters are common in assessment of asthma severity.

\section{RECOMMENDATIONS}

1- Encouraging physicians to adopt neutrophil to lymphocyte ratio as diagnostic measure and severity categorization of asthma.

2- Monitoring and following up asthmatic patients under management using neutrophil to lymphocyte ratio is hopeful.

3- Risk factors for neutrophil to lymphocyte ratio should be taken in consideration.

4- Further national large sized studies on neutrophil to lymphocyte ratio application in diagnosis and management of asthma must be supported.

\section{REFERENCES}

[1] Global Initiative for Asthma (GINA). Global strategy for asthma management and prevention. 2014. Available at:http://www.ginasthma.org.

[2] Uwaezuoke SN, Ayuk AC, Eze JN. Severe bronchial asthma in children: a review of novel biomarkers used as predictors of the disease. J Asthma Allergy 2018; 11:11-18. 
[3] Moore WC, Hastie AT, Li X. Sputum neutrophils are associated with more severe asthma phenotypes using cluster analysis. Journal of Allergy and Clinical Immunology 2014; 133: 1557-1563.

[4] Bloemen K, Van Den Heuvel R, Govarts E. A new approach to study exhaled proteins as potential biomarkers for asthma. Clinical and Experimental Allergy 2011; 41: 346-356.

[5] Imtiaz F, Shafique K, Mirza SS. Neutrophil lymphocyte ratio as a measure of systemic inflammation in prevalent chronic diseases in Asian population. International Archives of Medicine 2012; 5: 2.

[6] Zhang XY, Simpson JL, Powell H. Full blood count parameters for the detection of asthma inflammatory phenotypes. Clinical and Experimental Allergy 2014; 44: 1137-1145.

[7] Uthamalingam S, Patvardhan EA, Subramanian S. Utility of the neutrophil to lymphocyte ratio in predicting long-term outcomes in acute decompensated heart failure. Am J Cardiol 2011; 107(3):433438.

[8] Azab B, Bhatt VR, Phookan J. Usefulness of the neutrophil-to lymphocyte ratio in predicting short- and long term mortality in breast cancer patients. Ann Surg Oncol 2012; 19(1):217-224.

[9] de Jager CP, van Wijk PT, Mathoera RB, de Jongh-Leuvenink J,van der Poll T, Wever PC. Lymphocytopenia and neutrophillymphocyte count ratio predict bacteremia better than conventional infection markers in an emergency care unit. Crit Care 2010; 14(5): R192.

[10] Alkhouri N, Morris-Stiff G, Campbell C. Neutrophil to lymphocyte ratio: a new marker for predicting steatohepatitis and fibrosis in patients with nonalcoholic fatty liver disease. Liver Int 2012; 32(2):297-302

[11] Spark JI, Sarveswaran J, Blest N, Charalabidis P, Asthana S. An elevated neutrophil-lymphocyte ratio independently predicts mortality in chronic critical limb ischemia. J Vasc Surg 2010; 52(3):632-636.

12] Ouellet G, Malhotra R, Penne EL, Usvya L, Levin NW, Kotanko P.Neutrophil-lymphocyte ratio as a novel predictor of survival in chronic hemodialysis patients. Clin Nephrol 2016; 85(4):191-198.

[13] Chung KF. Targeting the interleukin pathway in the treatment of asthma. Lancet 2015; 386 (9998): 1086-1096.

[14] Jemal A, Bray F, Center MM, Ferlay J, Ward E, Forman D. Global cancer statistics. CA: A Cancer Journal for Clinicians 2011; 61 (2): 69-90.

[15] Gohy ST, Hupin C, Pilette C, Ladjemi MZ. Chronic inflammatory airway diseases: The central role of the epithelium revisited. Clinical and Experimental Allergy 2016; 46 (4): 529-542.

[16] Ekström M, Bornefalk-Hermansson A. Cardiovascular and antacid treatment and mortality in oxygen-dependent pulmonary fibrosis: A population-based longitudinal study. Respirology 2016; 21(4):705711

[17] Xu XF, Dai HP, Li YM, Xiao F, Wang C. Mass Spectrometry based Proteomics in Acute Respiratory Distress Syndrome: A Powerful Modality for Pulmonary Precision Medicine. Chin Med J (Engl) 2016; 129(19):2357-2364.

[18] Cardamone C, Parente R, Feo GD, Triggiani M. Mast cells as effector cells of innate immunity and regulators of adaptive immunity. Immunology Letters 2016; 178: 10-14.

[19] Li H, Yang T, Li FY, Ning Q, Sun ZM. TLR4 Overexpression inhibits endothelial PAS domain-containing protein 1 expression in the lower respiratory tract of patients with chronic COPD. Cellular Physiology and Biochemistry 2016; 39 (2): 685-692.

[20] Gheita TA, Gheita HA, Kenawy SA. Rituximab restored the muscle power and rescued from a refractory fatal respiratory failure in a patient with elderly-onset polymyositis. Joint Bone Spine 2012; 79 (1): 101-102.

[21] Konrad FM, Braun S, Ngamsri KC, Vollmer I, Reutershan J. Heme oxygenase- 1 attenuates acute pulmonary inflammation by decreasing the release of segmented neutrophils from the bone marrow. American Journal of Physiology. Lung Cellular andMolecular Physiology 2014; 307 (9): L707-L717.

[22] Rosales C, Demaurex N, Lowell CA, Uribe-Querol E. Neutrophils: Their role in innate and adaptive immunity. Journal of Immunology Research 2016, Article ID 1469780, 2 pages.

[23] Gordon CJ, Phillips PM, Ledbetter A, Snow SJ, Schladweiler MC, Johnstone AF, et al. Active vs. sedentary lifestyle from weaning to adulthood and susceptibility to ozone in rats. Am J Physiol Lung Cell Mol Physiol 2017; 312(1):L100-L109.

[24] Vargas A, Roux-Dalvai F, Droit A, Lavoie JP. Neutrophil-Derived Exosomes: A New Mechanism Contributing to Airway Smooth Muscle Remodeling. Am J Respir Cell Mol Biol 2016; 55(3):450-461.

[25] Global Initiative for Asthma, Global Strategy for Asthma Management and Prevention, GINA, Fontana, WI, USA, 2017.Available at: http://ginasthma.org/download/317/
[26] Wang F, He XY, Baines KJ. Different inflammatory phenotypes in adults and children with acute asthma," The European Respiratory Journal 2011; 38 (3): 567-574

[27] Khatry DB, Gossage DL, Geba GP, Parker JM, Jarjour NN, Busse WW, et al. Discriminating sputum-eosinophilic asthma: Accuracy of cutoffs in blood eosinophil measurements versus a composite index, ELEN. J Allergy Clin Immunol 2015; 136(3):812-814.e2.

[28] Simpson JL, Scott R, Boyle MJ, Gibson PG. Inflammatory subtypes in asthma: assessment and identification using induced sputum. Respirology 2006; 11(1):54-61.

[29] Kupczyk M, Dahlen B, Sterk PJ. Stability of phenotypes defined by physiological variables and biomarkers in adults with asthma. Allergy 2014; 69 (9): 1198-1204.

[30] Wang $\mathrm{M}$, Gao $\mathrm{P}$, Wu X. Impaired anti-inflammatory action of glucocorticoid in neutrophil from patients with steroidresistantasthma. Respir Res 2016; 17(1):153.

[31] Uribe Echevarría EM, Maldonado CA, Uribe Echevarría AM, Aoki A. Neutrophil predominance in induced sputum from asthmatic patients. Therapeutic implications and role of clara cell 16-KD protein. Medicina (B Aires) 2011; 71(4):343-349.

[32] Green BL, Wiriyachaiporn S, Grainge C. Potentially pathogenic airway bacteria and neutrophilic inflammation in treatment resistant severe asthma. PloS One 2014; 9 (6): article e100645.

[33] Alam R, Good J, Rollins D. Airway and serum biochemical correlates of refractory neutrophilic asthma. J Allergy Clin Immunol 2017; 140(4):1004-1014.e13.10

[34] Ito T, Hirose K, Norimoto A. Dectin-1 plays an important role in house dust mite-induced allergic airway inflammation through the activation of CD11b+ dendritic cells. Journal of Immunology 2017; 198 (1): 61-70.

[35] Mosca T, Menezes MC, Silva AV, Stirbulov R, Forte WC. Chemotactic and phagocytic activity of blood neutrophils inallergic asthma. Immunological Investigations 2015; 44 (5): 509-520.

[36] Siew LQC, Wu SY, Ying S, Corrigan CJ. Cigarette smoking increases bronchial mucosal IL-17A expression in asthmatics, which acts in concert with environmental aeroallergens to engender neutrophilic inflammation. Clin Exp Allergy 2017; 47(6):740-750.

[37] Doukas J, Eide L, Stebbins K. Aerosolized phosphoinositide 3-kinase gamma/delta inhibitor TG100-115 [3-[2,4-diamino-6-(3 hydroxyphenyl)pteridin-7-yl]phenol] as a therapeutic candidate forasthma and chronic obstructive pulmonary disease. The Journal of Pharmacology and Experimental Therapeutics 2009; 328 (3): 758765.

[38] Fung-Leung WP. Phosphoinositide 3-kinase delta (PI3Kdelta) in leukocyte signaling and function. Cellular Signalling 2011; 23 (4):603-608.

[39] Gupta V, Khan A, Higham A. The effect of phosphatidylinositol-3 kinase inhibition on matrix metalloproteinase-9 and reactiveoxygen species release from chronic obstructive pulmonary disease neutrophils. International Immunopharmacology 2016; 35: 155-162.

[40] Hsia BJ, Whitehead GS, Thomas SY. Trif-dependent induction of Th17 immunity by lung dendritic cells. Mucosal Immunology 2015; 8 (1): 186-197.

[41] Tang FS, Van Ly D, Spann K. Differential neutrophil activation in viral infections: Enhanced TLR-7/8-mediated CXCL8 release in asthma. Respirology 2015; 21(1):172-9.

[42] Tang FS, Foxley GJ, Gibson PG, Burgess JK, Baines KJ, Oliver BG. Altered Innate Immune Responses in Neutrophils from Patients with Well- and Suboptimally Controlled Asthma. Mediators Inflamm 2015; 2015:219374

[43] Page K, Lierl KM, Hughes VS, Zhou P, Ledford JR, Wills-Karp M. TLR2-mediated activation of neutrophils in response to German cockroach frass. J Immunol 2008; 180(9):6317-6324.

[44] McAlees JW, Whitehead GS, Harley IT. Distinct Tlr4-expressing cell compartments control neutrophilic and eosinophilic airway inflammation. Mucosal Immunology 2015; 8 (4): 863-873.

[45] Uller L, Persson CG, Erjefält JS. Resolution of airway disease:removal of inflammatory cells through apoptosis, egression or both? Trends Pharmacol Sci 2006; 27(9):461-466.

[46] Baines KJ, Simpson JL, Bowden NA, Scott RJ, Gibson PG. Differential gene expression and cytokine production from neutrophils in asthma phenotypes. The European Respiratory Journal 2010; 35 (3): 522-531.

[47] Simpson JL, Powell H, Boyle MJ, Scott RJ, Gibson PG.Clarithromycin targets neutrophilic airway inflammation in refractory asthma. American Journal of Respiratory and Critical Care Medicine 2008; 177 (2): 148-155.

[48] Côté O, Clark ME, Viel L. Secretoglobin 1A1 and 1A1A differentially regulate neutrophil reactive oxygen species production, 
phagocytosis and extracellular trap formation. PLoS One 2014; 9(4):e96217.

[49] Tian BP, Xia LX, Bao ZQ, Zhang H, Xu ZW, Mao YY, et al. Bcl- 2 inhibitors reduce steroid-insensitive airway inflammation. J Allergy Clin Immunol 2017; 140(2):418-430.

[50] Uddin M, Nong G, Ward J. Prosurvival activity for airway neutrophils in severe asthma. Thorax 2010; 65 (8): 684-689.

[51] Sikkeland LI, Johnsen HL, Riste TB, Alexis NE, Halvorsen B, Søyseth V, et al. Sputum neutrophils are elevated in smelter workers and systemic neutrophils are associated with rapid decline in FEV1. Occup Environ Med 2016; 73(7):459-466.

[52] Murad HA, Habib HS, Rafeeq MM, Sulaiman MI, Abdulrahman AS, Khabaz MN. Co-inhalation of roflumilast, rather than formoterol, with fluticasone more effectively improves asthma in asthmatic mice. Exp Biol Med (Maywood) 2017; 242(5):516-526.

[53] Yu JH, Long L, Luo ZX, You JR. Effect of PPARgamma agonist (rosiglitazone) on the secretion of Th2 cytokine in asthmamice. Asian Pacific Journal of Tropical Medicine 2017; 10 (1): 64-68.

[54] Liu J, Pang Z, Wang G. Advanced Role of Neutrophils in Common Respiratory Diseases. Journal of Immunology Research 2017,Article ID 6710278, 21 pages.

[55] Forget P, Khalifa C, Defour JP, Latinne D, Van Pel MC, De Kock M. What is the normal value of the neutrophil-to-lymphocyte ratio? BMC Res Notes 2017; 10(1):12.

[56] Gao H, Ying S, Dai Y. Pathological Roles of Neutrophil-Mediated Inflammation in Asthma and Its Potential for Therapy as a Target. J Immunol Res 2017; 2017:3743048.

[57] Gungen AC, Aydemir Y. The correlation between asthma disease and neutrophil to lymphocyte ratio. Res J Allergy Immunol 2017; 1(1):14.

[58] Duffy BK, Gurm HS, Rajagopal V, Gupta R, Ellis SG, Bhatt DL.Usefulness of an elevated neutrophil to lymphocyte ratio in predicting long-term mortality after percutaneous coronary intervention. Am J Cardiol 2006; 97: 993-996.

[59] Arbel Y, Finkelstein A, Halkin A, Birati EY, Revivo M, Zuzut M, et al. Neutrophil/lymphocyte ratio is related to the severity of coronary artery disease and clinical outcome in patients undergoing angiography. Atherosclerosis 2012; 225: 456-460.

[60] Gunay E, Ulasli SS, Akar O, Ahsen A, Gunay S, Koyuncu T, et al. Neutrophil-tolymphocyte ratio in chronic obstructive pulmonary disease: a retrospective study. Inflammation 2014; 37: 374-380.

[61] Nacaroglu HT, İsgüder R, Bent S, Erdem Bahceci S, Ceylan G, Korkmaz HA, et al. Can neutrophil/lymphocyte ratio be a novel biomarker of inflammation in children with asthma? European Journal of Inflammation 2016; 109-112. Available at: https://doi.org/10.1177/1721727X16660558

[62] Shi G, Zhao JW, Ming L. Clinical significance of peripheral blood neutrophil-lymphocyte ratio and platelet- lymphocyte ratio inpatients with asthma. Nan Fang Yi Ke Da Xue Xue Bao 2017; 37(1):84-88.

[63] Fu JJ, McDonald VM, Gibson PG, Simpson JL. Systemic inflammation in older adults with asthma-COPD overlap syndrome. Allergy Asthma Immunol Res 2014; 6:316-324.

[64] Brüünsgaard H, Pedersen BK. Age-related inflammatory cytokines and disease. Immunol Allergy Clin North Am 2003; 23: 15-39.

[65] Mochimaru T, Fukunaga K, Kuwae M, Watanabe R, Okuzumi S, B aba R, et al. Neutrophil to Lymphocyte Ratio Is a Novel Predictor of Severe Exacerbation in Asthma Patients. American Journal of Respiratory and Critical Care Medicine 2018; 197:A1406.

[66] Campo P, Rodr يguez F, Sánchez-García S. Phenotypes and endotypes of uncontrolled severe asthma: new treatments. J Investig Allergol Clin Immunol 2013; 23:76-88.

[67] Acarturk G, Acay A, Demir K, Ulu MS, Ahsen A, Yuksel S Neutrophil-to-lymphocyte ratio in inflammatory bowel disease - as a new predictor of disease severity. Bratisl Lek Listy 2015; 116(4):213217.

[68] Rice J, Dodge JL, Bambha KM, Bajaj JS, Reddy KR, Gralla J, et al. Neutrophil-to-Lymphocyte Ratio Associates Independently With Mortality in Hospitalized Patients With Cirrhosis. Clin Gastroenterol Hepatol 2018; 16(11):1786-1791.e1.

[69] Erdem E. Neutrophil lymphocyte ratio in aute renal failure. Indian J Nephrol 2015; 25(2):126-127.

[70] Hendy RM, Elawady MA, Mansour AI. Assessment of neutrophil/lymphocyte percentage in bronchial asthma. The Egyptian Journal of Chest Diseases and Tuberculosis 2019; 68:74-79.

[71] Bruijnzeel PL, Uddin M, Koenderman L. Targeting neutrophilic inflammation in severe neutrophilic asthma: can we target the diseaserelevant neutrophil phenotype? J Leukoc Biol 2015; 98(4):549-556.

[72] Tarraf H, Aydin O, Mungan D. Prevalence of asthma among the adul general population of five Middle Eastern countries: results of the SNAPSHOT program. BMC Pulm Med 2018; 18(1):68.
[73] Battaglia S, Benfante A, Spatafora M, Scichilone N. Asthma in the elderly: a different disease? Breathe (Sheff) 2016; 12(1):18-28.

[74] Imtiaz F, Shafique K, Mirza SS, Ayoob Z, Vart P, Rao S. Neutrophil lymphocyte ratio as a measure of systemic inflammation in prevalent chronic diseases in Asian population. Int Arch Med 2012; 5(1):2.

[75] Zein JG, Dweik RA, Comhair SA. Asthma Is More Severe in Older Adults. PLoS One 2015; 10(7):e0133490.

[76] Lin BD, Hottenga JJ, Abdellaoui A. Causes of variation in the neutrophil-lymphocyte and platelet-lymphocyte ratios: a twinfamily study. Biomark Med 2016; 10(10):1061-1072.

[77] Mohanan S, Tapp H, McWilliams A, Dulin M. Obesity and asthma: pathophysiology and implications for diagnosis and management in primary care. Exp Biol Med (Maywood) 2014;239(11):1531-1540.

[78] Hasan HA. Evaluation of the Relation between Asthma, Obesity and Leptin Level in Iraqi Asthmatic Patients and the Main Risk Factors that are Associated with Leptin Level. Iraqi J Pharm Sci 2011; 20(2): 96-101.

[79] Chhabra SK. Clinical application of spirometry in asthma: Why, when and how often?. Lung India 2015; 32(6):635-637.

[80] Lambert A, Drummond MB, Wei C. Diagnostic accuracy of FEV1/forced vital capacity ratio $\mathrm{z}$ scores in asthmatic patients. J Allergy Clin Immunol 2015; 136(3):649-653.e4.

[81] Melam GR, Buragadda S, Alhusaini A, Alghamdi MA, Alghamdi MS, Kaushal P. Effect of Different Positions on FVC and FEV1 Measurements of Asthmatic Patients. J Phys Ther Sci 2014; 26(4):591-593. 